\title{
Casein and soya-bean protein have different effects on whole body protein turnover at the same nitrogen balance
}

\author{
BY K. NIELSEN ${ }^{1}$, J. KONDRUP'*, P. ELSNER ${ }^{2}$, A. JUUL ${ }^{1}$ AND E. S. JENSEN ${ }^{3}$ \\ ${ }^{1}$ Clinical Nutrition Unit, Medical Department $A$ and Department of Growth and Reproduction, \\ Rigshospitalet, University Hospital, Copenhagen, Denmark \\ ${ }^{2}$ Department of Biochemistry A, The Panum Institute, Copenhagen, Denmark \\ ${ }^{3}$ Department of Environmental Science, National Laboratory, Risoe, Roskilde, Denmark
}

(Received 22 June 1993 - Revised 29 October 1993 - Accepted 16 November 1993)

\begin{abstract}
The present study examined whether different proteins have different effects on whole-body protein turnover in adult rats. The rats were either starved, given a protein-free but energy-sufficient diet ( $1 \mathrm{MJ} / \mathrm{kg}$ body weight (BW) per d) or a diet containing intact casein, hydrolysed casein, or hydrolysed soya-bean protein at a level of $9.1 \mathrm{~g} / \mathrm{kg} \mathrm{BW}$ per $\mathrm{d}$. The diets, which were isoenergetic with the same carbohydrate: fat ratio, were given as a continuous intragastric infusion for at least $\mathbf{4} \mathrm{d}$. During the last $19 \mathrm{~h}{ }^{15} \mathrm{~N}$-glycine (a primed continuous infusion) was given intragastrically and ${ }^{15} \mathrm{~N}$ was recovered from urinary ammonia and urea during isotope steady state for measurement of protein synthesis and protein degradation. Compared with starvation the protein-free diet decreased $N$ excretion by $75 \%$, probably by increasing the rate of reutilization of amino acids from endogenous proteins for protein synthesis. The protein diets produced a positive $\mathrm{N}$ balance which was independent of the protein source. Intact and hydrolysed casein increased protein synthesis 2.6- and 2.0-fold respectively, compared with the proteinfree diet. Protein degradation increased 1.4- and 1-2-fold respectively. Hydrolysed soya-bean protein did not increase protein synthesis but decreased protein degradation by $35 \%$ compared with the protein-free diet. Compared with the hydrolysed soya-bean protein, intact casein resulted in 2-2-and 2-8-fold higher rates of protein synthesis and degradation respectively. These results are not easily explained by known sources of misinterpretation associated with the ${ }^{15} \mathrm{~N}$-glycine method. Hydrolysed casein and hydrolysed soya-bean protein produced similar concentrations of insulin-like growth factor-1, insulin, glucagon, and corticosterone. The difference in amino acid composition between the dietary proteins was reflected in plasma amino acid composition and this is suggested to be responsible for the different effect on protein turnover. Preliminary results from this study have previously been published in abstract form (Nielsen et al. 1991).
\end{abstract}

Protein turnover: ${ }^{15} \mathbf{N}$-glycine: Casein: Soya-bean protein: Rat

Different preparations of identical proteins result in different growth rates of rats. Refeeding of starved rats with hydrolysed whey resulted in faster weight gain than refeeding with intact whey (Poullain et al. 1989, 1991) and hydrolysed casein gave a higher growth rate than intact casein (Zaloga et al. 1991). In the present study it was examined whether different proteins with equal nutritional quality affect whole-body protein synthesis and degradation differently. Adult rats were used in order to measure protein turnover in a state of $\mathrm{N}$ balance which reflects protein metabolism rather than regulation of growth. Continuous intragastric infusion of a liquid diet and of ${ }^{15} \mathrm{~N}$-glycine for measurement of whole-body protein turnover was employed.

In the first experiment three different commercial liquid formulas containing intact casein, hydrolysed casein or hydrolysed soya-bean protein were compared with a protein-

* For reprints. 
free diet, and with starvation. The three protein sources produced almost the same $\mathrm{N}$ balance but intact and hydrolysed casein increased protein synthesis and degradation while hydrolysed soya-bean protein decreased degradation.

In a second experiment the time course of isotope enrichment showed a clear difference in flux only $4-6 \mathrm{~h}$ after beginning isotope infusion. A third experiment with specially prepared diets which only differed in the protein source produced the same differences. Plasma concentrations of insulin, insulin-like growth factor 1 (IGF-1), glucagon, corticosterone and individual amino acids were also measured, allowing the tentative explanation that the difference was due to the different amino acid compositions of the proteins.

\section{METHODS \\ Operative procedures}

Female Wistar rats with a body weight of about $250 \mathrm{~g}$ (Møllegaard Breeding Center, Denmark) were anaesthetized by two consecutive injections (Hypnorm, Janssen, $0.2 \mathrm{ml} / 100 \mathrm{~g}$ body weight (BW) i.p.; diazepam $0.8 \mathrm{mg} / 100 \mathrm{~g} \mathrm{BW}$ i.p.). The hair over the scapula and abdomen was shaved and the skin painted with iodine. Liquid dressing (Nobecutane; Astra Meditec, Albertslūnd, Denmark) was sprayed on the skin and the rat was wrapped in plastic drape (Vita wrap; Good Year, Svendborg, Denmark). Using an aseptic operative technique, a $20 \mathrm{~mm}$ ventral midline incision was made in the skin of the abdomen and the stomach was mobilized. A polyethylene catheter (i.d. $0.78 \mathrm{~mm}$, o.d. $1.22 \mathrm{~mm}$ ) with a $1 \mathrm{~mm}$ collar at $10 \mathrm{~mm}$ from the distal part of the catheter was introduced into the forestomach through a puncture and sutured (4-0 silk suture) in the serosa and musculature around the catheter collar. Using a $100 \mathrm{~mm}$ cannula, the catheter was guided through the left side of the abdominal muscle layer approximately $20 \mathrm{~mm}$ from the incision, under the skin to the back and out between the scapulas. The midline incision was closed in layers using silk suture (4-0); the procedure took about $30 \mathrm{~min}$. The procedure is a modification of the technique described by Tsukamoto et al. (1984).

A rat 'jacket' (Alice King Chatham; Medical Arts, Hawthorne, CA, USA) was fitted to take the strain from the spring coil and swivel. The rat was then housed in a plexiglas metabolism cage and the catheter flushed with $1 \mathrm{ml}$ water once a day. A $6 \mathrm{~d}$ period was allowed for recovery after the operation and acclimatization to the metabolism cage in a thermostatically-controlled room with a $12 \mathrm{~h}$ artificial light-dark cycle. In this period the rats had free access to water and standard rat pellets (Altromin Werke, Lage, Germany). The rats lost an average of $15 \mathrm{~g} \mathrm{BW}$ during the first three postoperative days and then started to gain weight. On day 7 the experiments were performed as described below.

The rats were killed by exsanguination. Inspection of the abdominal cicatrice and catheter placement was performed to ensure the absence of infection.

\section{Experimental protocol}

Expt 1. On day 7 the rat pellets were removed and the rats were either starved for $4 \mathrm{~d}$ or given a $19 \mathrm{~h} / \mathrm{d}$ continuous infusion of a liquid diet (17.00 to 12.00 hours) for the next $4 \mathrm{~d}$. Urine was collected daily on days $8-11$ into plastic vessels containing $5 \mathrm{ml} 2 \mathrm{M}-\mathrm{HCl}$ and stored at $-20^{\circ}$ until analysis. ${ }^{15} \mathrm{~N}$-glycine infusion, as described below, was started on day 10 and urine was collected for measurement of isotope enrichment on day 11.

The diets were isoenergetic with the same carbohydrate (CHO): fat ratio, and were given as $1 \mathrm{MJ} / \mathrm{kg} \mathrm{BW}$ per d with $9 \cdot 1 \mathrm{~g}$ protein $/ \mathrm{kg} \mathrm{BW}$ per d when containing protein (Table 1). To ensure that observed differences were not due to different series of rats, only two or three out of the six rats in each series were given the same diet. The protein-free diet was made 
Table 1. Expt 1. Composition (\% energy) of the diets

\begin{tabular}{lcccc}
\hline \hline & \multicolumn{3}{c}{ Percentage of energy as } & \\
\cline { 2 - 4 } Diet* & Protein & CHO & Fat & MCT:LCT \\
\hline Protein-free & 0 & 65 & 35 & $0: 100$ \\
Intact casein $\dagger$ & 15 & 55 & 30 & $34: 66$ \\
Hydrolysed soya-bean protein & 15 & 55 & 30 & $50: 50$ \\
Hydrolysed casein $\ddagger$ & 12 & 53 & 35 & $14: 86$ \\
\hline \hline
\end{tabular}

CHO, carbohydrate; MCT, medium-chain triacylglycerols; LCT, long-chain triacylglycerols.

* The energy content of all diets was $4 \cdot 20 \mathrm{~kJ} / \mathrm{ml}$.

$\dagger$ Casein plus lactalbumin.

+ Casein plus whey protein.

of maltodextrin (Malto-Energi; Jensen Clinical Nutrition Service, Dianalund, Denmark), long-chain triacylglycerol (LCT) oil (Lipofundin, $100 \mathrm{mg} / \mathrm{ml}$, B. Braun Melsungen AG, Melsungen, Germany) and sterile water, but for technical reasons, without vitamins and minerals. The hydrolysed soya-bean protein diet was made from a commercially available formula diet (Top Up; Ferrosan Ltd., Copenhagen, Denmark) without modifications other than dilution with sterile water. This hydrolysate is produced by a mixture of bacterial proteases (MD Foods; Viby, J., Denmark). The intact casein diet was made from an intact casein formula diet (Salvimulsin MCT; Ercopharm Ltd, Vedbiek, Denmark) diluted with sterile water and supplemented with maltodextrin and LCT oil in order to obtain the same ratios of protein, fat and carbohydrate. The hydrolysed casein diet was made from a trypsin-digested casein-and-whey formula (Reabilan; Roussel Nutrition, Copenhagen, Denmark) diluted with sterile water. The protein, fat, $\mathrm{CHO}$ and amino acid compositions are shown in Tables 1 and 2 . The tables reproduce the manufacturers' information and the modifications mentioned above. The protein content was measured by us.

Expt 2. From day 7 two rats were given hydrolysed soya-bean protein and three were given intact casein (same diets as in Expt 1). The rise in atom percent excess (APE) was followed for $24 \mathrm{~h}$ and therefore the feeding period was extended from 19 to $24 \mathrm{~h} / \mathrm{d}$, but with the same amount of protein and energy/d. Infusion of ${ }^{15} \mathrm{~N}$-glycine was started on day 10 as described below except for omission of the priming dose.

Expt 3. This experiment was performed because the diets in the first and second experiments had differences other than the protein sources. The hydrolysed soya-bean protein diet was the same as above. The hydrolysed casein diet was prepared by Ferrosan Ltd. from casein (without whey) which was hydrolysed by almost the same procedure that was used to hydrolyse the soya-bean protein (MD Foods). By molecular weight (Da) the distribution of peptides in the soya-bean hydrolysate was as follows: $>5000,2 \%$; $5000-3000,1 \%, 3000-1000,28 \% ; 1000-500,35 \% ; 500-300,18 \% ;<300,16 \%$. In the casein hydrolysate the distribution of peptides was: $>5000,4 \% ; 5000-3000,11 \%$; $3000-1000,41 \% ; 1000-500,27 \% ; 500-300,10 \% ;<300,8 \%$. The protein-free diet was supplemented with L-methionine and L-tryptophan in the same amounts as the hydrolysed soya-bean protein and hydrolysed casein, and the diets contained the same $\mathrm{CHO}$ :fat ratio plus vitamins and minerals so that they differed only in the protein source.

After the pellets were removed on day 7, $4 \mathrm{~d}$ were allowed for assimilation to the new diet and 5 days were subsequently allowed for a more valid $\mathrm{N}$ balance, including faecal $\mathrm{N}$, before the isotope infusion. The amount of faeces had been neglected in Expt 1, since faecal output was zero or near zero during the first $4 \mathrm{~d}$ with the liquid diets. 
Table 2. Amino acid composition of the diets ( $\mathrm{mg} / \mathrm{g}$ crude protein)

\begin{tabular}{|c|c|c|c|c|}
\hline & \multirow[b]{2}{*}{$\begin{array}{l}\text { Intact } \\
\text { casein }\end{array}$} & \multirow{2}{*}{$\begin{array}{l}\text { Trypsin- } \\
\text { hydrolysed } \\
\text { casein }\end{array}$} & \multicolumn{2}{|c|}{$\begin{array}{l}\text { Bacterial protease- } \\
\text { hydrolysed }\end{array}$} \\
\hline & & & Casein & $\begin{array}{c}\text { Soya-bean } \\
\text { protein }\end{array}$ \\
\hline Lys & 77 & 85 & 67 & 68 \\
\hline Thr & 49 & 44 & 35 & 39 \\
\hline His & 26 & 25 & 28 & 24 \\
\hline Trp & 15 & 18 & 16 & 11 \\
\hline Phe + Tyr & 92 & 95 & 115 & 78 \\
\hline Met + Cys & 32 & 39 & 29 & 34 \\
\hline Leu & 111 & 101 & 107 & 67 \\
\hline Ile & 60 & 51 & 41 & 41 \\
\hline Val & 69 & 59 & 69 & 44 \\
\hline $\mathrm{Ala}$ & 29 & 36 & 30 & 39 \\
\hline Glu & 196 & 159 & 203 & 204 \\
\hline Asp & 65 & 84 & 59 & 125 \\
\hline Pro & 87 & 84 & 91 & 64 \\
\hline Arg & 34 & 33 & 39 & 82 \\
\hline Gly & 28 & 18 & 18 & 39 \\
\hline Ser & 38 & 47 & 43 & 45 \\
\hline
\end{tabular}

A $24 \mathrm{~h}$ continuous infusion of the liquid diets was employed in this experiment, as in Expt 2. Faeces and urine were collected on days 12-16 and stored at $-20^{\circ}$. In this Expt it was also attempted to measure protein synthesis in tissues directly by the intravenous ${ }^{3} \mathrm{H}$ phenylalanine flooding-dose technique, but due to lack of experience the infusion was successful only in a fraction of the rats, in particular in only two of the rats given hydrolysed soya-bean protein. This was evident from low radioactivity in plasma samples, low or unmeasurable plasma and tissue concentrations of phenylalanine and low values for radioactivity in tissue proteins. The results are not shown. Blood samples were taken for determination of hormones and plasma amino acid composition. Feeding was continued until anaesthesia was introduced (Thiomebumal i.p.; $10 \mathrm{mg} / 100 \mathrm{~g} \mathrm{BW}$ ), i.e. about $30 \mathrm{~min}$ before killing. The last portion of urine for determination of ${ }^{15} \mathrm{~N}$ (see below) was taken before the anaesthesia.

\section{Measurement of protein turnover}

A primed continuous intragastric infusion of ${ }^{15} \mathrm{~N}$-glycine $(98 \%$, Sigma) was initiated $19 \mathrm{~h}$ before the end of the experiment. A bolus of $5.94 \mathrm{mg}{ }^{15} \mathrm{~N} / \mathrm{kg} \mathrm{BW}$ was given over 5 min followed by a continuous infusion of $4.75 \mathrm{mg}{ }^{15} \mathrm{~N} / \mathrm{kg} \mathrm{BW}$ per $24 \mathrm{~h}$, added to the liquid diet. The ratio used between the doses of bolus and continuous infusion was the same as that used in human experiments (Jeevanandam et al. 1985) since we did not know beforehand the rate constant in rats. The results of Expt 2 showed that this did not affect the observed different effects of the proteins. The amount of ${ }^{15} \mathrm{~N}$-glycine administered during the continuous infusion was equal to about $8 \%$ of the amount of glycine given in the dietary proteins. Urine was collected hourly during the period of plateau enrichment (15-19 h) for analysis of ${ }^{15} \mathrm{~N}$ in urinary urea and ammonia.

A preinfusion urine sample was used to determine the ${ }^{15} \mathrm{~N}$ background. Based on the method described by Jensen (1991), urinary ammonia was isolated by adding $4 \mathrm{ml}$ saturated $\mathrm{K}_{2} \mathrm{CO}_{3}$ to a $4 \mathrm{ml}$ portion of urine in a closed bottle and absorbing the evolved 
ammonia on a $1 / 425 \mathrm{~mm} \mathrm{GF} / \mathrm{C}$ glass filter (Whatman) containing $50 \mu 10.5 \mathrm{M}-\mathrm{H}_{2} \mathrm{SO}_{4} . \mathrm{A}$ diffusion time of $48 \mathrm{~h}$ was used which gave a recovery of about $90 \%$ of the ammonia. Urine $(2 \mathrm{ml})$ was treated with $1 \mathrm{ml}$ resin (Amberlite IR-120 Plus; Sigma) to remove ammonia, and subsequently incubated in a closed bottle with urease for $1 \mathrm{~h}$ at $37^{\circ}$ and $\mathrm{pH} 6.5$ to convert urea to ammonia. Then $4 \mathrm{ml}$ saturated $\mathrm{K}_{2} \mathrm{CO}_{3}$ was added and ammonia was trapped as described above. After the diffusion procedure, filters were dried under atmospheric air for $1 \mathrm{~h}$ before they were placed in tin capsules. The samples were analysed using an elemental analyser (Carlo Erba NA1500) coupled to an isotope-ratio mass spectrometer (Finnigan MAT Delta; Jensen, 1991). Flux was calculated from the APE at plateau ${ }^{15} \mathrm{~N}$ enrichment by the method of Picou \& Taylor-Roberts (1969) by using the geometric average of APE in ammonia and urea (Fern et al. 1985a). Protein synthesis and degradation were calculated according to the equation:

$$
\mathrm{Q}=\mathrm{I}+\mathrm{D}=\mathrm{E}+\mathrm{S}
$$

in which $\mathrm{Q}$ is flux, $\mathrm{I}$ is intake, $\mathrm{D}$ is degradation, $\mathrm{E}$ is excretion as urinary $\mathrm{N}$ and $\mathrm{S}$ is synthesis. The rates are expressed per $\mathrm{kg}$ final $\mathrm{BW}$.

The procedures were approved by the Ethical Committee for laboratory animals in Denmark.

\section{Analytical}

$\mathrm{N}$ contents in urine, faeces and diets were measured by a micro Kjeldahl technique (Keltec System; Tecator AB, Hoganaes, Sweden). Urine was measured once, faeces and diet in duplicate. Plasma insulin and glucagon were determined by commercially available kits from Novo Nordisk Ltd., Copenhagen, Denmark, with intra-assay variations of $5 \cdot 0$ and $5.3 \%$ respectively. Corticosterone was measured by the kit supplied by Farmos Diagnostica, Turku, Finland with an intra-assay variation of $2 \cdot 2 \%$. IGF-1 in serum was determined after acid-ethanol extraction as described by Bang et al. (1991). Measurements of IGF-1 standard solutions in serum were parallel to the standard curve. The intra-assay variation was $3.9 \%$. Due to large inter-assay variations each hormone was measured in all samples on the same day. Plasma amino acid composition was measured by the Pico-Tag ${ }^{\circledR}$ method, Waters Chromatography Division, Milford, Mass., USA.

\section{Statistics}

The data were analysed by one-way ANOVA. When significant differences were found, Tukey's procedure was used to make comparisons within a group with $P<0.05$ considered significant. The results were presented as means with standard errors of the difference.

\section{RESULTS \\ Expt 1}

The protein-free diet improved $\mathrm{N}$ balance (i.e. intake (I) - urinary excretion $(\mathrm{E})$; $\mathrm{N}$ in faeces was not measured; Table 3) compared with starvation. This was associated with a lower rate of excretion, increased protein synthesis and decreased degradation. $\mathrm{N}$ balance was positive and not significantly different with the protein diets. The amount of protein administered was intended to be equal in all three groups but the $\mathbf{N}$ content of the hydrolysed casein diet, measured after the experiment, turned out to be lower than stated by the manufacturer. In the protein-fed groups urea and ammonia accounted for $91 \%$ and $3 \%$ of total $\mathrm{N}$ excretion respectively, without differences between the groups.

Intact and hydrolysed casein increased protein synthesis $2 \cdot 5-$ and $2 \cdot 0$-fold respectively, compared with the protein-free diet, and intact casein increased protein degradation 1.4- 
Table 3. Expt 1. Whole-body protein turnover in rats that were starved or given diets containing no protein, intact casein, hydrolysed casein or hydrolysed soya-bean protein* (Mean values for four or five rats)

\begin{tabular}{|c|c|c|c|c|c|c|}
\hline \multirow[b]{2}{*}{ Diet } & \multicolumn{6}{|c|}{$\mathrm{g}$ protein $/ \mathrm{kg}$ BW per $\mathrm{d}$} \\
\hline & I-E & $\mathrm{Q}_{\text {geo }}$ & I & $\mathrm{D}$ & E & $\mathbf{S}$ \\
\hline Starved $(n 5)$ & $-6 \cdot 35^{\mathrm{a}}$ & $8.79^{\mathrm{a}}$ & 0.00 & $8 \cdot 79^{\text {bd }}$ & $6 \cdot 35^{\mathrm{bc}}$ & $2 \cdot 44^{a}-(-3)$ \\
\hline Protein-free $(n 5)$ & $-1 \cdot 59^{\mathrm{b}}$ & $6 \cdot 51^{\mathrm{b}}$ & 0.00 & $6 \cdot 51^{2}$ & $1 \cdot 59^{a}$ & $4.92^{\circ}$ \\
\hline Intact casein $(n 4)$ & $2 \cdot 81^{\mathrm{c}}$ & $18 \cdot 32^{\mathrm{c}}$ & $8.95^{\mathrm{a}}$ & $9 \cdot 37^{\mathrm{bcd}}$ & $6 \cdot 14^{\mathrm{bc}}$ & $12 \cdot 18^{\mathrm{b}}$ \\
\hline $\begin{array}{l}\text { Hydrolysed soya-bean } \\
\text { protein }(n 4)\end{array}$ & $1.99^{\mathrm{c}}$ & $12 \cdot 78^{\mathrm{d}}$ & $9.07^{\mathrm{a}}$ & $3 \cdot 71^{c}$ & $7.08^{b}$ & $5 \cdot 70^{c}$ \\
\hline Hydrolysed casein $(n 4)$ & $2.06^{\mathrm{c}}$ & $15 \cdot 78^{\mathrm{e}}$ & $8.03^{\mathrm{b}}$ & $7 \cdot 75^{\mathrm{d}}$ & $5.97^{\mathrm{e}}$ & $9 \cdot 81^{\mathrm{d}}$ \\
\hline SED, $n_{\mathrm{x}} 4 \& n_{\mathrm{y}} 4$ & 0.34 & 0.74 & 0.14 & 0.65 & 0.35 & 0.63 \\
\hline $\mathrm{SED}, n_{\mathrm{x}} 4 \& n_{\mathrm{y}} 5$ & 0.32 & 0.71 & 0.14 & 0.62 & 0.34 & 0.60 \\
\hline SED, $n_{\mathrm{x}} 5 \& n_{\mathrm{y}} 5$ & $0 \cdot 30$ & 0.66 & 0.13 & 0.58 & 0.32 & 0.57 \\
\hline
\end{tabular}

BW, body weight; I, protein intake; $E$, urinary nitrogen excretion $\times 6.25 ; \mathrm{Q}_{\mathrm{geo}}$, flux; $\mathrm{D}$, protein degradation; $S$, protein synthesis; SED, standard error of the difference between means.

a,b,c,d,e Mean values within each column with unlike superscripts were significantly different $(P<0 \cdot 05)$

* For details of diets and procedures, see Tables 1 and 2, and pp. 70-73.

fold. The difference between intact and hydrolysed casein was probably due to the lower protein administration in the latter group. Protein synthesis was not increased significantly by hydrolysed soya-bean protein but degradation was decreased by $43 \%$, compared with the protein-free diet.

When compared with hydrolysed soya-bean protein, intact casein increased protein synthesis and degradation $2 \cdot 1$ - and $2 \cdot 5$-fold respectively. With hydrolysed casein the protein synthesis and degradation were $1 \cdot 7$ - and $2 \cdot 1$-fold higher compared with hydrolysed soyabean protein.

Table 4 shows flux calculated from APE of ammonia $\left(Q_{a}\right)$ or from APE of urea $\left(Q_{u}\right)$ Compared with starvation the protein-free diet decreased $Q_{a}$ but not $Q_{u}$. Intact and hydrolysed casein increased both $\mathrm{Q}_{\mathrm{a}}$ and $\mathrm{Q}_{\mathrm{u}}$ more than did hydrolysed soya-bean protein.

\section{Expt 2}

Fig. 1 shows that the APE of both ammonia and urea were higher after about $4 \mathrm{~h}$ of isotope infusion with hydrolysed soya-bean protein compared with casein. With both proteins the APE in ammonia was higher than in urea. With casein the quasi-plateau enrichments were reached in about 5 and $8 \mathrm{~h}$ for ammonia and urea respectively, whereas the plateau enrichment was reached in about 11 and $18 \mathrm{~h}$ for ammonia and urea with hydrolysed soyabean protein.

\section{Expt 3}

The protein diets gave almost the same positive $\mathrm{N}$ balance as in Expt 1, although in this experiment it was determined during the last $5 \mathrm{~d}$ of the $9 \mathrm{~d}$ experiment (Table 5; I-E in the table does not include faeces). Faecal $\mathrm{N}$ excretion was variable but similar in the three groups (equivalent to $0.40-0.49 \mathrm{~g}$ protein $/ \mathrm{kg} \mathrm{BW}$ per d). Before the operation the rats given the protein-free diet weighed 247 (SE 4) $\mathrm{g}$. After $7 \mathrm{~d}$ with pellets $a d$ lib. and $5 \mathrm{~d}$ with the protein-free diet, i.e. $4 \mathrm{~d}$ before termination of the experiment, the weight was 226 (SE 5) $\mathrm{g}$ and on the day of killing the weight was 218 (SE 6) $\mathrm{g}$. The rats given the protein diets weighed 248 (SE 2) g before the operation, $4 \mathrm{~d}$ before termination they weighed 239 (SE 3) $\mathrm{g}$ 
Table 4. Protein synthesis and degradation calculated from atom percent excess $(A P E)$ in urinary ammonia and urea, in rats that were starved or given diets containing no protein, intact casein, hydrolysed casein or hydrolysed soya-bean protein*

(Mean values for four or five rats)

\begin{tabular}{|c|c|c|}
\hline \multirow[b]{2}{*}{ Diet } & \multicolumn{2}{|c|}{ g protein $/ \mathrm{kg} \mathrm{BW}$ per $\mathrm{d}$} \\
\hline & $Q_{\mathbf{a}}$ & $\mathrm{Q}_{\mathrm{u}}$ \\
\hline Starved $(n 5)$ & $7 \cdot 98^{\text {ad }}$ & $9 \cdot 68^{\mathrm{a}}$ \\
\hline Protein free $(n 5)$ & $4 \cdot 83^{\mathrm{b}}$ & $8 \cdot 79^{a}$ \\
\hline Intact casein $(n 4)$ & $15 \cdot 09^{c e}$ & $22 \cdot 30^{\mathrm{b}}$ \\
\hline Hydrolysed soya-bean protein $(n 4)$ & $9.98^{d e}$ & $16 \cdot 45^{\mathrm{c}}$ \\
\hline Hydrolysed casein $(n 4)$ & $12 \cdot 72^{\mathrm{e}}$ & $19 \cdot 65^{\mathrm{d}}$ \\
\hline SED, $n_{\mathrm{x}} 4 \& n_{\mathrm{y}} 4$ & $0 \cdot 95$ & $0 \cdot 74$ \\
\hline SED, $n_{\mathrm{x}} 4 \& n_{\mathrm{y}} 5$ & 0.90 & $0 \cdot 70$ \\
\hline $\mathrm{SED}, n_{\mathrm{x}} 5 \& n_{\mathrm{y}} 5$ & 0.85 & $0 \cdot 66$ \\
\hline
\end{tabular}

BW, body weight; $Q_{a}$, protein flux calculated from APE in ammonia; $Q_{u}$, protein flux calculated from APE in urea; SED, standard error of the difference between means.

$a, b, c, d, e$ Mean values within each column with unlike superscript letters were significantly different $(P<0.05)$.

* For details of diets and procedures, see Tables 1 and 2, and pp. 70-73.

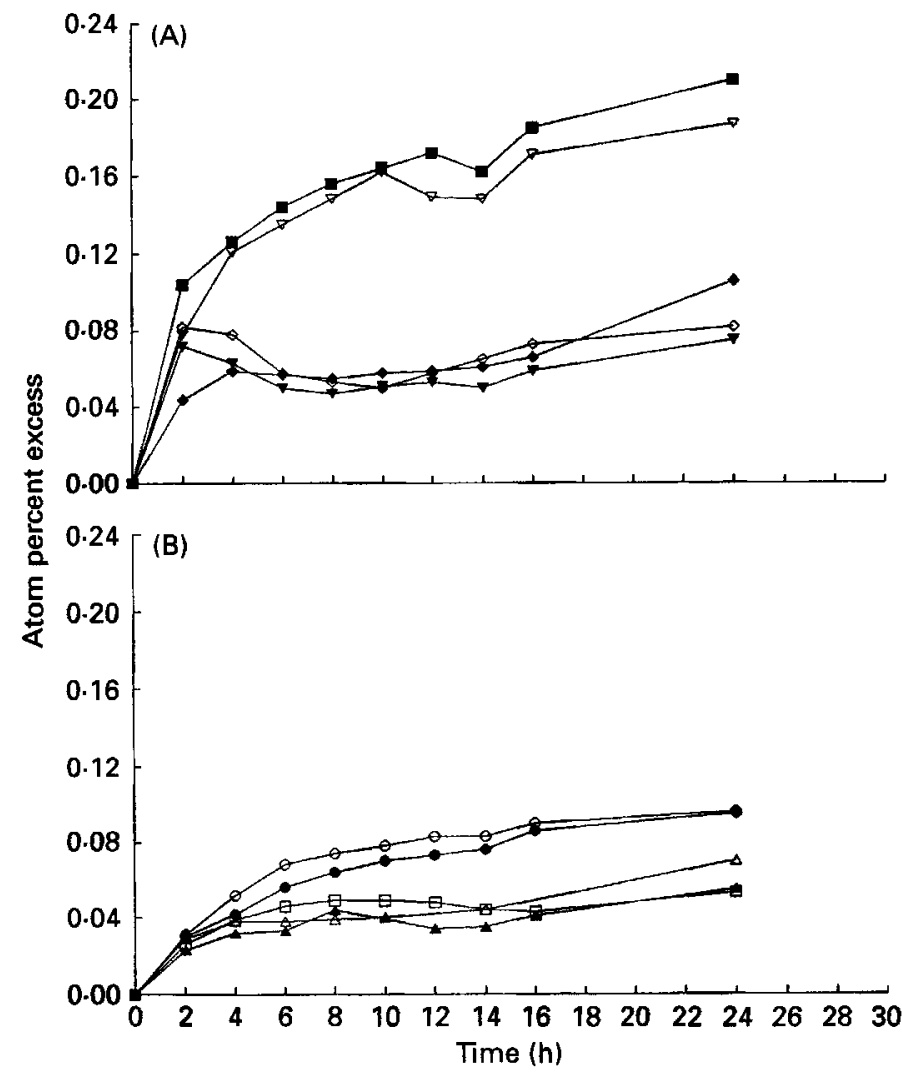

Fig. $1 .{ }^{15} \mathrm{~N}$ enrichment of urinary ammonia (A) and urea (B) during continuous infusion of ${ }^{15} \mathrm{~N}$-glycine in two rats given hydrolysed soya-bean protein $(O, O, \square, \nabla)$ and in three rats given intact casein. $(\triangle, \Delta, \nabla, \square$, $\diamond, \diamond)$. 


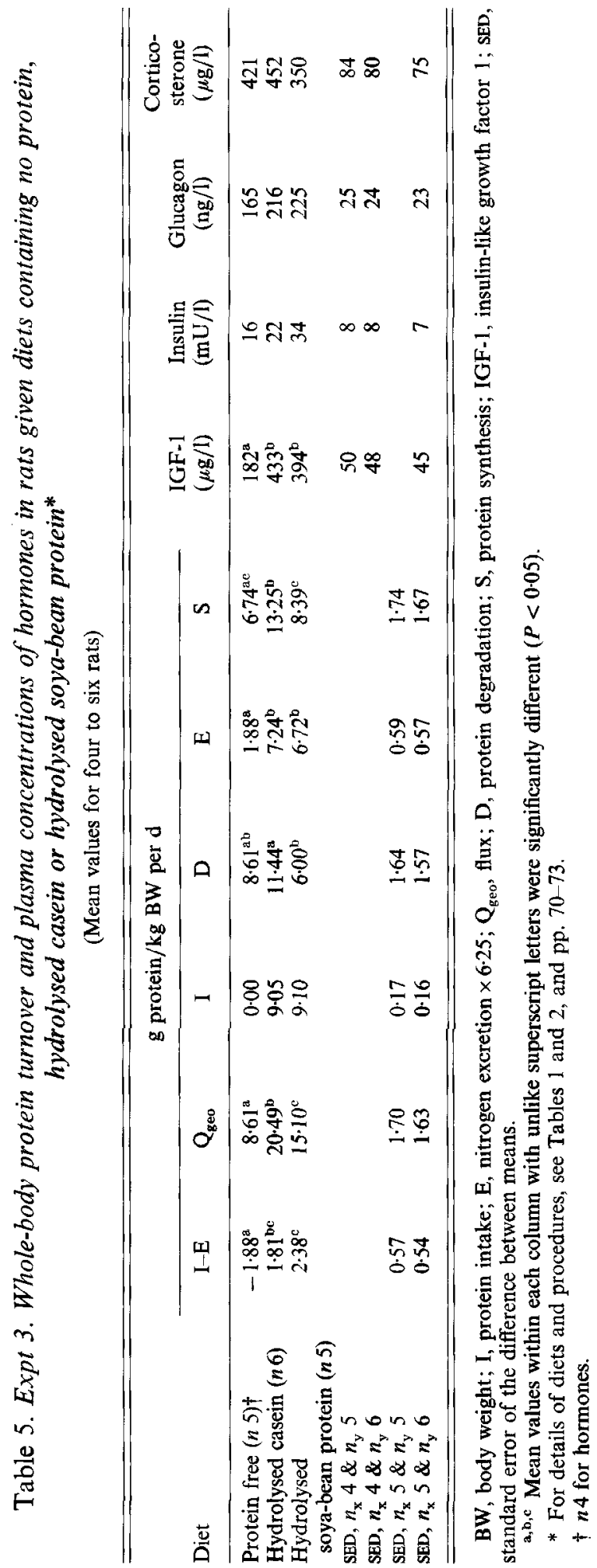


Table 6. Expt 3. Plasma amino acid concentrations ( $\mu$ mol/l) during feeding, in rats given diets containing no protein, hydrolysed casein or hydrolysed soya-bean protein*

(Mean values for four to six rats)

\begin{tabular}{|c|c|c|c|c|c|c|}
\hline $\begin{array}{l}\text { Amino } \\
\text { acid }\end{array}$ & $\begin{array}{l}\text { Protein-free } \\
(n 4)\end{array}$ & $\begin{array}{l}\text { Hydrolysed } \\
\text { casein } \\
(n 6)\end{array}$ & $\begin{array}{l}\text { Hydrolysed } \\
\text { soya-bean } \\
\text { protein } \\
(n 5)\end{array}$ & $\begin{array}{c}\text { SED } \\
n_{\mathrm{x}} 4 \& \\
n_{\mathrm{y}} 6\end{array}$ & $\begin{array}{c}\text { SED } \\
n_{\mathrm{x}} 4 \& \\
n_{\mathrm{y}} 5\end{array}$ & $\begin{array}{c}\text { SED } \\
n_{\mathrm{x}} 5 \& \\
n_{\mathrm{y}} 6\end{array}$ \\
\hline Lys & 567 & 668 & 632 & 66 & 69 & 62 \\
\hline Thr & $65^{\mathrm{a}}$ & $397^{\mathrm{b}}$ & $354^{b}$ & 57 & 59 & 53 \\
\hline His & 57 & 46 & 48 & 6 & 6 & 5 \\
\hline Trp & 66 & 81 & 69 & 10 & 10 & 9 \\
\hline Met & $35^{\natural}$ & 43 & $54^{b}$ & 7 & 7 & 6 \\
\hline Leu & $80^{\mathrm{a}}$ & $124^{b}$ & 104 & 11 & 12 & 11 \\
\hline Ile & $37^{a}$ & $71^{\mathrm{b}}$ & $95^{\mathrm{b}}$ & 10 & 10 & 9 \\
\hline Val & $90^{\mathrm{a}}$ & $205^{b}$ & $174^{b}$ & 19 & 20 & 18 \\
\hline Ala & $565^{\mathrm{a}}$ & $379^{b}$ & 459 & 59 & 61 & 55 \\
\hline Glu & $156^{\mathrm{a}}$ & $81^{b}$ & $75^{\mathbf{b}}$ & 21 & 22 & 20 \\
\hline Gln & $659^{a}$ & $461^{b}$ & $439^{b}$ & 48 & 50 & 45 \\
\hline Asp & 14 & 7 & 9 & 3 & 3 & 3 \\
\hline Asn & 48 & 50 & 71 & 9 & 9 & 8 \\
\hline Pro & $147^{\mathrm{a}}$ & $245^{\mathrm{b}}$ & 206 & 30 & 31 & 28 \\
\hline Arg & $117^{b}$ & $120^{b}$ & $173^{\mathrm{a}}$ & 15 & 16 & 14 \\
\hline Orn & 46 & $31^{a}$ & $57^{\mathrm{a}}$ & 8 & 9 & 8 \\
\hline Gly & $380^{\mathrm{a}}$ & $129^{b}$ & $202^{\mathrm{b}}$ & 36 & 38 & 34 \\
\hline Ser & $392^{\mathfrak{a}}$ & $151^{\mathrm{b}}$ & $243^{c}$ & 31 & 33 & 29 \\
\hline Total & 3521 & 3290 & 3465 & 265 & 275 & 249 \\
\hline
\end{tabular}

SED, standard error of the difference between means.

$\mathbf{a}, \mathbf{b}, \mathbf{e}$ Mean values within each row with unlike superscript letters were significantly different $(P<0.05)$.

* For details of diets and procedures, see Tables 1 and 2, and pp. 70-73.

and on the day of killing they weighed 247 (SE 4) g. There was no difference in growth rate between the groups fed on the different proteins.

Hydrolysed casein increased synthesis $2 \cdot 0$-fold compared with the protein-free diet while degradation was not increased significantly. With hydrolysed soya-bean protein compared with the protein-free diet the effect on $\mathrm{Q}_{\text {geo }}$ was similar to that in Expt 1 but the $30 \%$ decrease in degradation did not reach statistical significance. As in Expt 1, hydrolysed soyabean protein did not increase synthesis significantly. Hydrolysed casein compared with hydrolysed soya-bean protein gave a 1.6-fold higher rate of synthesis and a 1.9-fold higher rate of degradation.

Both proteins significantly increased the plasma concentration of IGF-1 while the changes in insulin, glucagon and corticosterone were insignificant.

Table 6 shows the changes in individual and total amino acids. Values for phenylalanine and tyrosine are not shown since they resulted from the (partially unsuccessful) ${ }^{3} \mathrm{H}$ phenylalanine injection (see p. 72). The total concentration of other amino acids did not differ between the groups. Compared with the protein-free diet, hydrolysed casein significantly increased the concentrations of threonine, leucine, valine, isoleucine and proline, and decreased the concentrations of glutamate, glutamine, alanine, glycine and serine. The changes with hydrolysed soya-bean protein compared with the protein-free diet were similar except that arginine increased, methionine was significantly increased and the changes in alanine, proline and leucine were insignificant. With hydrolysed soya-bean protein compared with casein the mean concentration of all plasma amino acids, except 
isoleucine and serine, changed in the direction that could be expected from the difference in amino acid composition of the proteins, but the difference was significant only for arginine, ornithine and serine.

\section{DISCUSSION}

The decrease in urinary $\mathrm{N}$ excretion caused by the protein-free diet compared with starvation (Table 3) was probably due to reduced gluconeogenesis from amino acids originating from endogenous proteins. This was associated with an increased reutilization of endogenous amino acids for protein synthesis (S/Q increased from $28 \%$ to $76 \%$ ) and a decreased protein degradation as calculated from $\mathrm{Q}_{\mathrm{geo}}$. The latter effect, however, was largely due to a decrease in $Q_{a}$ while $Q_{u}$ was only marginally decreased (Table 4). In contrast to urea, only a limited number of amino acids contribute quantitatively to the formation of urinary ammonia. Glutamine has been estimated to contribute about $60 \%$ in the acidotic dog (Pitts, 1974) and in healthy human subjects (Jungas et al. 1992). The results suggest that energy supply did not decrease total amino acid flux $\left(Q_{u}\right)$, i.e. protein degradation, but increased reutilization of liberated amino acids for protein synthesis at the expense of $\mathbf{N}$ excretion and formation of glutamine, decreasing $Q_{a}$.

The protein diets resulted in positive $\mathrm{N}$ balance. When faecal $\mathrm{N}$ is subtracted from the mean $\mathrm{N}$ balance (I-E) in Expt 3 (Table 5) the retention is about $1.7 \mathrm{~g}$ protein $/ \mathrm{kg} \mathrm{BW}$ per d. This would equal an expected weight gain of about $7-9 \mathrm{~g} / \mathrm{kg} \mathrm{BW}$ per $\mathrm{d}$ which compares well with the observed weight gain of about $8 \mathrm{~g} / \mathrm{kg} \mathrm{BW}$ per $\mathrm{d}$. The aim of $\mathrm{N}$ balance was not achieved, possibly because the rats after the operation had only fully regained their weight loss towards the end of the experiment.

The difference in protein turnover between the protein-free and the starved state illustrates that it is not a trivial problem to select the control group when studying protein metabolism. The effect of casein was to increase synthesis but not degradation when compared with the starved state, while it increased both synthesis and degradation when compared with the protein-free state.

Our results suggest that the positive $\mathrm{N}$ balance achieved with intact or hydrolysed casein or hydrolysed soya-bean protein was obtained in two different ways: casein increased protein synthesis (and degradation) whereas soya-bean protein decreased protein degradation and did not significantly increase synthesis. The fact that the soya-bean protein was hydrolysed was not responsible for the difference since the effect of two different hydrolysed preparations of casein gave nearly the same effect as did intact casein.

The protein diets gave different rates of flux, depending on whether ammonia or urea was used for the calculation (Table 4), but the two proteins affected flux in the same direction whether expressed in terms of ammonia or urea.

According to the two-compartment model discussed by Fern et al. (1985a) the geometric fluxes presented for the protein diets in Table 3 are probably not more than about $10 \%$ different from the true values of $N$ flux, since the $Q_{a}: Q_{u}$ ratio with the three protein diets varied from $0.61-0.68$. The similarity of these ratios also indicates that the different effects of the proteins are not due to selective effects on flux of amino acids equilibrating with urinary ammonia compared with amino acids equilibrating with urea.

The ${ }^{15} \mathrm{~N}$-glycine method is an indirect method for measuring protein synthesis and degradation and, under basal feeding conditions, the ${ }^{15} \mathrm{~N}$-glycine method gives almost the same results as obtained with uniformly ${ }^{15} \mathrm{~N}$-labelled egg, yeast or wheat protein or with ${ }^{14}$ C-labelled leucine (Golden \& Jackson 1981; Fern et al. 1985b). However, with a change in conditions the assumptions of the method need to be reconsidered. According to the analysis of the method (Golden \& Jackson, 1981) the higher APE with soya-bean protein could, rather than being due to effects on protein synthesis and degradation, be due to: (1) 
the increased proportion of glycine and serine in hydrolysed soya-bean protein, (2) a possible increase in rates of glycine and serine de novo synthesis, or (3) to different degrees of exchange of ${ }^{15} \mathrm{~N}$ from glycine to other amino acids. These changes could by themselves increase the APE of the end products and cause a decrease in calculated flux. We have evaluated these possibilities by adopting the principles of calculation described by Golden \& Jackson (1981). In Expt 1 the measured APE of urea was 0.114 (SE 0.004) with intact casein while it was 0.167 (SE 0.006) with hydrolysed soya-bean protein. At rates for synthesis and degradation obtained with intact casein the $27 \%$ higher content of glycine and serine in soya-bean protein would itself increase the APE to $0 \cdot 126$. This means that $((0 \cdot 126-0 \cdot 114) \times$ $100 / 0 \cdot 167-0 \cdot 114)=22 \%$ of the difference between the two proteins can be explained by the difference in content of glycine and serine. An additional nearly 6-fold increase in de novo synthesis would be required to increase the APE to the measured value. Arnstein \& Neuberger (1953) reported that the rate of de novo synthesis of glycine and serine in rats was independent of the content of these amino acids in the diet. In humans, de novo synthesis of glycine was unaffected by changing the amount of mixed amino acids in the diet but omission of non-essential amino acids reduced de novo synthesis by about $30 \%$ (Yu et al. 1985). Glucose infusion did not change de novo glycine synthesis in humans (Robert et al. 1982). From available evidence it seems that de novo synthesis of glycine and/or serine is rather constant during various experimental conditions and it is not obvious that soyabean protein with a higher content of glycine + serine should increase de novo synthesis of these amino acids to the extent required to explain the difference in APE.

If adding to the effect of the increased dietary content of glycine and serine a change in the distribution of the dose of label from $50 \%$ in glycine and serine (which are assumed to be equally labelled) and $50 \%$ in all other amino acids (Golden \& Jackson, 1981; Matthews et al. 1981) to an equal distribution in all amino acids, or to a distribution in glycine and serine only (Jackson \& Golden 1980), calculated values of APE of 0.115 and 0.137 respectively are obtained. The pattern of distribution may change with the amount of ${ }^{15} \mathrm{~N}$ glycine administered and the infusion time (Jackson \& Golden, 1980; Matthews et al. 1981) but the pattern does not change substantially under a variety of metabolic conditions such as feeding, fasting, refeeding, hypophysectomy, or treatment with growth hormone or corticotropin (Gaebler et al. 1959; Vitti \& Gaebler, 1963; Jackson \& Golden, 1980). It is not likely that the different proteins could produce highly different patterns of distribution, and even in the extreme case a change in distribution cannot fully explain the effect of soyabean protein.

Despite these calculations it cannot be entirely ruled out that the indirect nature of the ${ }^{15} \mathrm{~N}$-glycine method and the disparate amino acid composition of the diets used led to artefacts that are more severe than we have been able to calculate. This could be elucidated by direct measurement of protein synthesis in individual tissues, as was attempted unsuccessfully with the flooding-dose technique in the last experiment.

Expt 2 (Fig. 1) showed that the difference between the proteins also existed without the priming bolus. The differences in time to reach the plateau enrichments agree with the differences in flux calculated from plateau enrichments (Table 4).

In Expt 3 the diets were identical except for the protein sources, and casein was hydrolysed almost by the same procedure that was used for hydrolysis of soya-bean protein. In this experiment the effects of the two proteins were approximately the same as in the previous experiments. The concentration of IGF-1 increased equally with the two proteins, as expected during protein feeding (Clemmons \& Underwood, 1991). Also insulin, glucagon and corticosterone were similar with both proteins and the different effects on whole-body protein turnover cannot be explained by these hormones.

With hydrolysed casein there were increases in the plasma concentrations of all essential 
amino acids (significant for branched-chain amino acids (BCAA) and threonine), compared with the protein-free diet. Garlick \& Grant (1988) found that BCAA alone stimulated muscle protein synthesis in vivo in fasted rats to the same extent as did a complete mixture of amino acids, when infused together with glucose (which increased plasma insulin to the levels found in the present study). The stimulated protein synthesis with hydrolysed casein could be due to the content of BCAA and the fed-state concentrations of IGF-1 and insulin.

With hydrolysed soya-bean protein the conditions for stimulation of protein synthesis were apparently similar. Still, essential amino acids could be limiting for protein synthesis with hydrolysed soya-bean protein, due to the decreased degradation observed. With hydrolysed casein (Expt 3 ) the total availability of essential amino acids from the diet was $4.68 \mathrm{~g} / \mathrm{kg} \mathrm{BW}$ per d. By assuming $48 \%$ essential amino acids in tissue proteins (value from food tables) an additional $(0.48 \times 11.44)=5.49 \mathrm{~g} / \mathrm{kg} \mathrm{BW}$ per $\mathrm{d}$ would be available from degradation of endogenous sources. The protein synthesis observed with casein would require $(0.48 \times 13.25)=6.36 \mathrm{~g} / \mathrm{kg} \mathrm{BW}$ per $\mathrm{d}$ as essential amino acids. Available essential amino acids were then used with an efficiency of $(6 \cdot 36 \times 100 / 4.68+5.49)=63 \%$. The same rate of synthesis would require an efficiency of $(6.36 \times 100) /(3.73+0.48 \times 6.00)=96 \%$ with the rate of degradation observed with hydrolysed soya-bean protein. Instead, an efficiency of $61 \%$ was observed which is similar to the efficiency with casein. It may be that the primary effect of hydrolysed soya-bean protein was to inhibit protein degradation which led secondarily to decreased synthesis.

With casein the slight increase in protein degradation could be due to the decrease in the plasma concentration of most non-essential amino acids (significant for glutamate, glutamine, alanine, glycine and serine compared with the protein-free diet). Hydrolysed soya-bean protein had higher contents of aspartate, arginine, serine and glycine which were reflected in higher plasma concentrations of arginine, ornithine and serine (and insignificant increases for asparagine and glycine). It may be that the higher content of one or several of these amino acids could be responsible for the decreased degradation with soya-bean protein. Leucine (or $\alpha$-ketoisocaproic acid) is probably the main regulatory amino acid for protein degradation in liver and muscle (Fulks et al. 1975; Mitch \& Clark, 1984; Miotto et al. 1992) but, at least in liver, the non-essential amino acids glutamine, alanine and glycine further decrease protein degradation when leucine is present (Mortimore et al. 1989; Miotto et al. 1992).

This study demonstrates that two different dietary proteins induce different kinetics of ${ }^{15} \mathrm{~N}$-labelled glycine. This is associated with changes in the plasma amino acid composition that reflect the difference in the amino acid composition of the dietary proteins. The isotope results are not easily explained by differences other than the suggested changes in protein synthesis and degradation. However, the results should be verified by direct measurement of protein synthesis in individual tissues and an explanation for the observation should be verified experimentally.

The P. Carl Petersen Foundation and the Danish Medical Research Council (J. nr. 129539) are acknowledged for their financial support. Ferrosan Ltd., Copenhagen, Denmark is acknowledged for preparation of the special diets and Novo Nordisk Ltd., Copenhagen, Denmark, for a generous supply of kits for determination of insulin and glucagon. The skilful assistance of technician Liselotte Hansen is gratefully acknowledged.

\section{REFERENCES}

Arnstein, R. V \& Neuberger, A. (1953). The synthesis of glycine and serine by the rat. Biochemical Journal 55, 271-280. 
Bang, P., Eriksson, U., Sara, V., Wivall, I-L. \& Hall, K. (1991). Comparison of acid ethanol extraction and acid gel filtration prior to IGF-I and IGF-II radioimmunoassays: improvement of determinations in acid ethanol extracts by the use of truncated IGF-I as radioligand. Acta Endocrinologica 124, 620-629.

Clemmons, D. R. \& Underwood, L. E. (1991). Nutritional regulation of IGF-I and IGF binding protein. Annual Reviews of Nutrition 11, 393-412.

Fern, E. B., Garlick, P. J. \& Waterlow, J. C. (1985a). The concept of the single body pool of metabolic nitrogen in determining the rate of whole-body nitrogen turnover. Human Nutrition: Clinical Nutrition 39C, 85-99.

Fern, E. B., Garlick, P. J. \& Waterlow, J. C. (1985b). Apparent compartmentation of body nitrogen in one human subject: its consequences in measuring the rate of whole-body protein synthesis with ${ }^{15} \mathrm{~N}$. Clinical Science 68 , 271-282.

Fulks, R. M., Li, J. B. \& Goldberg, A. L. (1975). Effects of insulin, glucose, and amino acids on protein turnover in rat diaphragm. Journal of Biological Chemistry 250, 290-298.

Gaebler, O. H., Glovinsky, R., Lees, H., Kurrie, D. \& Choitz, H. G. (1959). Effects of growth hormone and corticotropin on metabolism of $\mathrm{N}^{15}$ from glycine, L-alanine, and ammonium citrate. Endocrinology 65, 283-292.

Garlick, P. J. \& Grant, I. (1988). Amino acid infusion increases the sensitivity of muscle protein synthesis in vivo to insulin. Effect of branched-chain amino acids. Journal of Biochemistry 254, 579-584.

Golden, M. H. N. \& Jackson, A. A. (1981). Assumptions and errors in the use of ${ }^{15} \mathrm{~N}$-excretion data to estimate whole body protein turnover. In Nitrogen Metabolism in Man, pp. 323-343 [J. C. Waterlow and J. M. L. Stephen, editors]. London: Applied Science Publishers.

Jackson, A. A. \& Golden, M. H. N. (1980). ${ }^{15}$ N Glycine metabolism in normal man: the metabolic $\alpha$-aminonitrogen pool. Clinical Science 58, 517-522.

Jensen, E. S. (1991). Evaluation of automated analysis of ${ }^{15} \mathrm{~N}$ and total $\mathrm{N}$ in plant material and soil. Plant and Soil 133, 83-92.

Jeevanandam, M., Brennan, M. F., Horowitz, G., Rose, D., Mihranian, M. H., Daly, J. \& Lowry, S. F. (1985). Tracer priming in human protein turnover studies with ${ }^{15} \mathrm{~N}$ glycine. Biochemical Medicine 34, 214-225.

Jungas, R. L., Halperin, M. L. \& Brosnan, J. T. (1992). Quantitative analysis of amino acid oxidation and related gluconeogenesis in humans. Physiological Reviews 72, 419-448.

Matthews, D. E., Conway, J. M., Young, V. R. \& Bier, D. M. (1981). Glycine nitrogen metabolism in man. Metabolism 30, 886-893.

Miotto, G., Venerando, R., Khurana, K. K., Siliprandi, N. \& Mortimore, G. E. (1992). Control of hepatic proteolysis by leucine and isovaleryl-L-carnitine through a common locus. Journal of Biological Chemistry 267, 22066-22072.

Mitch, W. E. \& Clark, A. S. (1984). Specificity of the effects of leucine and its metabolites on protein degradation in skeletal muscle. Biochemical Journal 222, 579-586.

Mortimore, G., Pösö, A. \& Lardeux, B. R. (1989). Mechanism and regulation of protein degradation in liver. Diabetes Metabolism Reviews 5, 49-70.

Nielsen, K., Pedersen, A., Jensen, E. J. \& Kondrup, J. (1991). Different proteins have different effects on protein synthesis and degradation. Clinical Nutrition 10 (Suppl. 2), 6.

Picou, D. \& Taylor-Roberts, T. (1969). Measurement of total protein synthesis and catabolism and nitrogen turnover in infants in different nutritional states and receiving different amounts of dietary protein. Clinical Science 36, 283-296.

Pitts, R. F. (1974). Renal regulation of acid-base balance. In Physiology of the Kidney and Body Fluids, pp. 198-241. Chicago: Year Book Medical Publishers.

Poullain, M. G., Cezard, J. P., Marche, C., Macry, J., Roger, L., Grasset, E. \& Broyart, J. P. (1991). Effects of dietary whey proteins, their peptides or amino-acids on the ileal mucosa of normally fed and starved rats. Clinical Nutrition 10, 49-54.

Poullain, M. G., Cezard, J. P., Roger, L. \& Mendy, F. (1989). Effect of whey proteins, their oligopeptide hydrolysates and free amino acid mixtures on growth and nitrogen retention in fed and starved rats. Journal of Parenteral and Enteral Nutrition 13, 382-386.

Robert, J-J., Bier, D. M., Zhao, X. H., Matthews, D. E. \& Young, V. R. (1982). Glucose and insulin effects on de novo amino acid synthesis in young men: studies with stable isotope labeled alanine, glycine, leucine, and lysine. Metabolism 31, 1210-1218.

Tsukamoto, H., Reidelberger, R. D., French, S. W. \& Largman, C. (1984). Long-term cannulation model for blood sampling and intragastric infusion in the rat. American Journal of Physiology 247, R595-R599.

Vitti, T. G. \& Gaebler, O. H. (1963). Effects of growth hormone on metabolism of nitrogen from several amino acids and ammonia. Archives of Biochemistry and Biophysics 101, 292-298.

Yu, Y. M., Yang, R. D., Matthews, D. E., Wen, Z. M., Burke, J. F., Bier, D. M. \& Young, V. R. (1985). Quantitative aspects of glycine and alanine nitrogen metabolism in postabsorptive young men: effects of level of nitrogen and dispensable amino acid intake. Journal of Nutrition 115, 399-410.

Zaloga, G. P., Ward, K. A. \& Prielipp, R. C. (1991). Effect of enteral diets on whole body and gut growth in unstressed rats. Journal of Parenteral and Enteral Nutrition 15, 42-47. 